\title{
Comparative Efficacy of Aqueous Extract of three Botanicals on Corn Earworm (Heliothis armigera)
}

\author{
Ime Okon Udo* and Paulinus Titus Ibanga \\ Department of Crop Science, University of Uyo, \\ P.M.B. 1017, Uyo, Nigeria \\ "Corresponding author's email: imeudo [AT] yahoo.com
}

\begin{abstract}
A field research was conducted at Ikpe Annang, Essien Udim Local Government Area of Akwa Ibom State, Nigeria between March and June, 2015 to evaluate the efficacy of aqueous extract of Azadirachta indica, Moringa oleifera and Ocimum grattissimum on corn earworm (Heliothis armigera). The experiment was laid out in split plot fitted into randomized complete block design with three replicates. Aqueous extracts of the three botanicals were applied at the rates of 0, 100, 200 and $300 \mathrm{l} / \mathrm{ha}$ weekly to study the number of punch holes on leaves and the number of cobs attacked by corn earworm at 4, 6 and 8 weeks after planting (WAP), as well as grain yield. Data collected were subjected to analysis of variance (ANOVA) and significant means compared using least significant difference (LSD) at 5\% probability $(p<0.05)$. The results from the study showed that application of $A$. indica and $M$. oleifera leaf extracts applied at $300 \mathrm{l} / \mathrm{ha}$ recorded fewer punch holes than $\mathrm{O}$. grattissimum leaf extract, at different times after planting. At harvest, the application of neem leaf at 3001/ha recorded lesser number (1.49) of insect pest per cob than scent leaf (2.51) and moring a leaf (1.80) while fewer number of cobs were attacked by the insect pest. At harvest, the highest grain yield of 2.31 t/ha was recorded from maize treated with moringa leaf extract while neem leaf recorded 2.25 t/ha, as against scent leaf with the lowest yield of 1.85 t/ha. The incorporation of biopesticides particularly neem and moringa for the management of field pests of maize is hereby advocated.
\end{abstract}

Keywords--- Neem, moringa, scentleaf, efficacy, aqueous extract, corn earworm, maize.

\section{INTRODUCTION}

In Nigeria, and indeed most sub-sahara Africa, maize (Zea mays L.) attains economic importance from its value as staple food item (contributing to household food security), animal feed, agro-industrial and trade item, thereby leading to the growth of economy and poverty alleviation [1], [2], [3]. Yield-constraining factors include inefficient production technology, low-level plant health management skill, low capital outlay and inefficient resource utilization [4], [5]. The factors that limit maize production are also diverse, some of the most important ones being insects and closely related organisms such as mites. From the high valleys of the tropics and subtropics to the tropical lowlands and temperate regions, these pests can infest maize at any stage of crop development and in storage and attack any part of the plant, often causing severe damage [6].

Pest control in Africa has largely depended on the use of synthetic pesticides. Therefore, fears concerning the effect of synthetic pesticides on human health, increased pest resistance and the negative environmental impact of these chemicals have led to the development of safer, more environmentally acceptable and cost effective control alternatives, especially the use of plant products [7]. Most plants have insecticidal properties which have been used against ectoparasites, and or as antihelmintics or vermicides [8]. There is a good potential of using botanical pesticides as grain protectants in storage systems because they are broad spectrum besides being readily available, safer and affordable by resource poor farmers [9]. In Nigeria, most farmers are unaware of the availability of numerous and easily available plant-based insecticides. Plant - based insecticides must therefore be taken to the field to determine their efficacy against pests. Moringa (Moringa oleifera), Neem (Azadiracta indica), Scent leaf (Ocimum gratissimum), are useful plants known to man and have been found useful (especially among rural dwellers) in the treatment of malaria, diabetes, hypertension, gastritis/ulcers, heart burn, asthma, impotence and stress [10].

Corn earworm is a serious insect pest of cultivated maize and if left unchecked could cause considerable yield losses. This therefore gave impetus to this work to determine the efficacy of neem, moringa and scent leaf in the management of this insect pest. 


\section{MATERIALS AND METHODS}

\subsection{Experimental Site and cropping history}

The experiment was sited at Mbiabong Ikpe, Essien Udim Local Government Area of Akwa Ibom State, Nigeria during the early planting season of 2015. The experimental area falls under humid tropical rain forest zone of Nigeria and is located on latitude $15^{\circ} \mathrm{N}$ and $17^{\circ} \mathrm{N}$ and longitude $11^{\circ} \mathrm{E}$ and $13^{\circ} \mathrm{E}$ with mean altitude of about $68 \mathrm{~m}$ above sea level [11]. The rainfall pattern is bimodal with wet season starting from March - October and dry season from November - February. There is always a short dry spell in the raining season which occurs in the month of August and is characterised as August Break [12]. Mean annual temperature ranges from $25.28-27.51^{\circ} \mathrm{C}$ and could be high in the months of February - April while the relative humidity is between $69-81 \%$. The soil in the area has been described as typical acid sand soil [13].

\subsection{Preparation of aqueous extract}

Fresh leaves of neem, moringa and scentleaf were collected from the wild and air-dried for 5 days in the laboratory before being ground into fine powder using hand blender. After grinding, they were separately soaked in distilled water at the concentration of $5 \mathrm{~g} / 1000 \mathrm{ml}$ for about $12 \mathrm{hours}$, and then filtered to have an aqueous extract.

\subsection{Treatments}

The treatments were applied weekly at the rates of 0,100, 200 and 300lit/ha using a knapsack sprayer. The dimension of the entire plot was $12 \mathrm{~m} \times 49 \mathrm{~m}$, each replicate measuring $3 \mathrm{~m} \times 47 \mathrm{~m}$ with $1 \mathrm{~m}$ path between sub-plots, and $1.5 \mathrm{~m}$ between replicates.

Ten plants were tagged for insect pests' data and the following parameters were measured;

(a) Number of punched holes in stem and leaves at different times after planting

(b) Insect pest severity. This was determined using numbers in rating the level of severity (1 - low severity , 2 slightly severe, 3 - very severe)

(c) number of insects per bisect stem/ cob

(d) Number of cobs per plot attacked by insects

(e) Grain yield (t/ha)

\section{RESULTS AND DISCUSSION}

\subsection{Number of punch holes}

The result of number of punch holes recorded in Table 1 shows plots treated with 300, 200, 1001/ha aqueous extract of neem, moringa or scent leaf showing considerable reduction of insect pest damage compared to the untreated plots. This could be as a possible presence of bioactive compounds in the botanicals and agrees with the findings of [14] that some secondary metabolites may act both as insecticides and antifeedants thus influencing insect's locomotion, oviposition, feeding behaviour, developmental and physiological processes as well as behavioural patterns. The number of holes on leaf was significantly reduced by the different biopesticides compared with the untreated control. The significant decrease in the number of punch holes at harvest with the application of neem leaf extract suggested the presence of strong anti-feedant compounds and this agrees with the findings of [15] that neem extract blocks the synthesis and release of moulting hormones from the immature insects. This observation was also reported by [16], that azadirachtin does not directly kill pest, but alters the life-processing behaviour in such a manner that the insect can no longer feed, breed or undergo metamorphosis. 
Table 1: Effect of the extracts on number of punched holes recorded.

\begin{tabular}{|c|c|c|c|c|}
\hline \multirow[t]{2}{*}{ Treatment } & \multirow[t]{2}{*}{ Rate } & \multicolumn{3}{|c|}{ Weeks after planting } \\
\hline & & 4 & 8 & 12 \\
\hline \multirow[t]{4}{*}{ Neem } & 0 & 2.60 & 7.45 & 13.60 \\
\hline & 100 & 1.31 & 2.11 & 5.59 \\
\hline & 200 & 1.16 & 2.08 & 4.36 \\
\hline & 300 & 0.01 & 1.86 & 3.17 \\
\hline \multicolumn{2}{|c|}{ Mean } & 1.27 & 3.39 & 6.68 \\
\hline \multicolumn{2}{|c|}{ LSD } & 0.51 & 0.63 & 2.30 \\
\hline \multirow[t]{4}{*}{ Scent leaf } & 0 & 2.96 & 8.01 & 12.75 \\
\hline & 100 & 1.45 & 3.81 & 7.36 \\
\hline & 200 & 1.20 & 2.66 & 5.11 \\
\hline & 300 & 0.31 & 2.12 & 2.81 \\
\hline \multicolumn{2}{|c|}{ Mean } & 1.48 & 4.15 & 7.01 \\
\hline \multicolumn{2}{|c|}{ LSD } & 0.20 & 0.22 & 0.57 \\
\hline \multirow[t]{6}{*}{ Moringa } & 0 & 2.51 & 7.55 & 13.70 \\
\hline & 100 & 1.22 & 2.25 & 6.14 \\
\hline & 200 & 0.98 & 2.15 & 4.16 \\
\hline & 300 & 0.12 & 2.06 & 2.84 \\
\hline & & 1.21 & 3.50 & 6.71 \\
\hline & & 0.57 & 0.85 & 1.75 \\
\hline
\end{tabular}

\subsection{Insect Pest severity}

The severity of insect pests of maize was significantly different $(\mathrm{P}<0.05)$ among the biopesticides $($ Table 2$)$ compared with the untreated control. The 3001/ha treatment rate recorded the least insect pest severity at different times after treatment. This is an indication of the botanicals being able to offer protection to treated plants against pest attack.

Table 2: Insect pests' severity at different times after planting and at harvest.

\begin{tabular}{|c|c|c|c|c|c|}
\hline \multirow[t]{2}{*}{ Treatment } & \multirow[t]{2}{*}{ Rate } & \multicolumn{3}{|c|}{ weeks after planting } & \multirow[b]{2}{*}{ At harvest } \\
\hline & & 4 & 6 & 8 & \\
\hline \multirow{4}{*}{ Neem } & 0 & 2.67 & 3.11 & 4.25 & 4.75 \\
\hline & 100 & 1.60 & 1.71 & 1.85 & 2.04 \\
\hline & 200 & 1.35 & 1.68 & 1.56 & 1.89 \\
\hline & 300 & 1.25 & 1.34 & 1.48 & 1.59 \\
\hline \multicolumn{2}{|c|}{ Mean } & 1.80 & 1.96 & 2.27 & 2.53 \\
\hline \multicolumn{2}{|c|}{ LSD } & 0.20 & 0.38 & 0.22 & 0.57 \\
\hline \multirow[t]{4}{*}{ Scent leaf } & 0 & 2.67 & 3.22 & 4.30 & 4.63 \\
\hline & 100 & 1.68 & 1.81 & 1.98 & 2.27 \\
\hline & 200 & 1.48 & 1.63 & 1.65 & 2.12 \\
\hline & 300 & 1.38 & 1.62 & 1.80 & 1.95 \\
\hline \multicolumn{2}{|c|}{ Mean } & 1.57 & 1.93 & 2.14 & 2.42 \\
\hline \multicolumn{2}{|c|}{ LSD } & 0.51 & 0.25 & 0.63 & 2.30 \\
\hline \multirow[t]{6}{*}{ Moringa } & 0 & 2.70 & 3.25 & 4.40 & 4.75 \\
\hline & 100 & 1.58 & 1.65 & 1.70 & 1.93 \\
\hline & 200 & 1.30 & 1.51 & 1.60 & 1.85 \\
\hline & 300 & 1.42 & 1.50 & 1.63 & 1.78 \\
\hline & & 1.56 & 1.79 & 2.12 & 2.35 \\
\hline & & 1.25 & 1.61 & 1.78 & 1.86 \\
\hline
\end{tabular}




\subsection{Number of insects and maize grain yield}

Number of insect pest per stem presented in Table 3 showed significant differences amongst the treatments with highest number of insects recorded on the control treatment. The influence of biopesticide application on maize grain yield (Table 3) also varied significantly according to treatment level. Application of 300 1/ha resulted in the highest grain yield in all the treatments while the least grain yield was from the control treatment.

At harvest, the number of insect pests per stem was markedly influenced by the rates of application with plants treated with neem leaf extract at 3001/ha recording the lowest number. Maize yield was highest in plots treated with 3001/ha of the extracts which is an indication of greater protection of treated plots against the untreated control. Thus the significant reduction in infestation and damage accompanied by yield increases with application of moringa and neem leaf extracts on cultivated maize agrees with the findings of [17], [18] that biopesticides offered protection to crops than the untreated control.

Table 3: Number of cobs attacked by corn earworm (Heliothis armigera) and grain yield ( $t / h a)$

\begin{tabular}{|c|c|c|c|c|}
\hline Treatment & Rate & $\begin{array}{l}\text { Number } \\
\text { Of Insect } \\
\text { Pest per cob }\end{array}$ & $\begin{array}{l}\text { Number of cob } \\
\text { per plot attacked } \\
\text { by corn earworm }\end{array}$ & $\begin{array}{l}\text { Maize } \\
\text { Grain } \\
\text { Yield (t/ha) }\end{array}$ \\
\hline \multirow[t]{4}{*}{ Neem } & 0 & 6.39 & 5.33 & 1.18 \\
\hline & 100 & 2.75 & 3.13 & 1.95 \\
\hline & 200 & 2.14 & 1.88 & 2.15 \\
\hline & 300 & 1.49 & 1.33 & 2.25 \\
\hline \multicolumn{2}{|c|}{ Mean } & 3.19 & 2.92 & 1.88 \\
\hline \multicolumn{2}{|c|}{ LSD } & 0.65 & 0.53 & 0.20 \\
\hline \multirow[t]{4}{*}{ Scent leaf } & 0 & 5.75 & 6.34 & 1.12 \\
\hline & 100 & 3.99 & 3.88 & 1.85 \\
\hline & 200 & 3.05 & 2.51 & 2.10 \\
\hline & 300 & 2.51 & 2.01 & 2.10 \\
\hline \multicolumn{2}{|c|}{ Mean } & 3.83 & 3.69 & 1.79 \\
\hline \multicolumn{2}{|c|}{ LSD } & 1.80 & 1.60 & 0.95 \\
\hline \multirow[t]{6}{*}{ Moringa } & 0 & 6.11 & 5.14 & 1.11 \\
\hline & 100 & 2.80 & 2.75 & 1.96 \\
\hline & 200 & 2.42 & 1.99 & 2.20 \\
\hline & 300 & 1.80 & 1.52 & 2.31 \\
\hline & & 3.28 & 2.85 & 1.89 \\
\hline & & 0.57 & 0.85 & 0.97 \\
\hline
\end{tabular}

\section{CONCLUSION}

This study has shown that application of biopesticides in the management of insect pests of maize can reduce losses and optimize yield. Therefore, biopesticides could be incorporated in the management of insect pest of maize leading to a reduction in the environmental health hazard caused by chemical pesticides.

Conflict of interest: The authors declare none

\section{REFERENCES}

[1] Effa, E. B., Uwah, D. F., Iwo, G. A., Obok, E. E. and Ukoha, G. O. (2012). Yield Performance of Popcorn (Zea mays L. everta) under Lime and Nitrogen Fertilization on an Acid Soil. Journal of Agricultural Science, 4 (10): 12- 19.

[2] Farid, A., Khan, M. I. N.,Khan, A., Khattak, S. U. K., Sattar, A. and Sattar, A. (2007). Studies on Maize Stem 
Borer, Chilo partellus in Peshawar Valley. Pak. Journal of Zoology, 39 (2): 127-131.

[3] Tena, W. and Beyene, S. (2011). Identification of Growth Limiting Nutrients in Alfisols: Soil Physicochemical properties, Nutrient Concentrations and Biomass Yield of Maize. Journal of Sustainable Tropical Agricultural Research, 24(1): 23-35.

[4] Anon, M. (2012). Maize Supply to Local Industries in Nigeria: the Feasibility Report. Available at http://www.foramfera.com/index.php/investment-opportunities- in- $\quad$ nigeira/item/146-supplyingmaize-to-local industries- in-Nigeria-how-viable. Accessed on 10/10/2015.

[5] Badmus, M. A. and Ariyo, O. S. (2011).Forecasting Cultivated Areas and Production of Maize in Nigeria using ARIMA Model.Asian. Journal of Agricultural Science, 3 (3): 171-176.

[6] Kamanula J., Sileshi G. W., Belmain S. R., Sola P., Mvumi B. M. and Nyirenda G. K. (2010). Farmers' Insect Pests Management Practices and Pesticidal Plant use in the Protection of Stored Maize and Beans in Southern Africa. International Journal of Pest Management, 57(1): 41-49.

[7] Grzywacz, D.and Leavett, R.(2012). Biopesticides and their Role in Modern Pest Management in West Africa. African Journal of Agricultural Science, 117: 313-318.

[8] Hellpap, C. (2000). Steps for Developing Botanical Pesticides.Gate Information Service.Available on http://www.cplbookshop.com).Accessed on 8/12/ 2015.

[9] Udo, I.O. (2005). Evaluation of the Potential of some Local Spices as Stored Grain Protectants against Maize Weevil Sitophilus zeamais Mots (Coleoptera: Curculionidae). Journal of Applied Science and Environmental Management, 9 (1): 165-168.

[10] Kasolo, J. N., Bimenya, G. S., Ojok, L., Ochieng, J. and Ogwal-Okeng, J. W.(2010). Phytochemicals and uses of Moringa oleifera Leaves in Ugandan Rural Communities. Journal of Medicinal Plant Research, 4(9): 753-757.

[11] UCCDA (1998). Uyo Capital City Development Agency. Meteorological report and weather forecast. Uyo: UCCDA. P.25

[12] Udo, E. J. (1997). Clayed mineralogy of five surface soils under different drainage condition. Nigeria Journal of Science, 11: $315-317$.

[13] Loganathan, P. and Sutton, P. M. (1986). Phosphorus fraction and availability in solid form in different geological deposit in the Niger Delta of Nigeria. Journal of Soil Science, 143:16 - 25

[14] Udo, I.O. (2011). Potentials of Zanthoxylum xanthoxyloides (LAM.) for the Control of Stored Product Insect Pests. Journal of Stored Products and Postharvest Research 2(3): 40-44.

[15] Isman, M. B. (2006). Botanical Insecticides, Detergents, and Repellants in Modern Agriculture and an Increasingly Regulated World. Annu. Revised Entomology, 51:45-66.

[16] Elahi, K. M (2008).Social Forestry, Exotic Trees and Moringa. The Daily Star Published 6 sept. Available at URL:http://www.thedailystar.net/story.php?nid=53438. Accessed on 2/3/2016.

[17] Okweche, S. I. and Umoetok, S. B. A. (2012).The Distribution of Maize Stem Borers in Cross

River State,

Nigeria. International Journal of Animal and Environmental Science. 2(1): 82-86.

[18] Khan, S. M. and Amjad, M. (2000). Chemical Control of Maize Stem Borer (Chilo partellus Swin.). Journal of Biological Science, 3(12): 2116-2118. 